\title{
The Greens in the German Federal Elections of $2013^{1}$
}

\author{
Wolfgang Rüdig \\ School of Government and Public Policy, University of Strathclyde \\ w.rudig@strath.ac.uk
}

The German Greens had a disappointing election outcome on 22 September 2013. Its $8.4 \%$ of the vote, well below its record $10.7 \%$ in 2009 , left the party shocked and dispirited.

\section{Campaign Preparations: Leadership and Programme}

The Greens entered the election year in fairly confident mood. Support for the party peaked well above 20\% shortly after the Fukushima nuclear accident in March 2011. ${ }^{2}$ This was followed by a strong run of record results in state elections, which saw the Greens represented in all 16 regional parliaments for the first time and in several regional coalition governments.

In late 2012, Green party members for the first time directly elected the party's two 'lead candidates': Jürgen Trittin, former Environment Minister, and Katrin GöringEckardt, an East German who held a high office in the Evangelical Church. While Trittin represented the left-wing of the party, Göring-Eckardt's surprise election was interpreted as a strong sign that the membership also wanted to have more conservative views represented.

The election programme passed by a party conference in April 2013 was, however, widely regarded as a move to the left. A substantial document, the book version running to 336 pages, it contained a wide range of very detailed policies, including more emphasis on social justice and proposing a wide range of tax increases. The programme reflected the ideological changes since the end of the red-green coalition in 2005. The economic policies of that government, in particular the Hartz IV reforms, were seen by many Greens as a mistake because they had contributed to the creation of a large low-paid sector of 'precarious' employment and increasing inequality.

Media commentators noted the boldness of a party going into an election campaign with a programme imposing a major financial burden on its own well-heeled supporters. However, the poll rating of the Greens - which had stabilised around 1314\% throughout 2012 and early 2013 - appeared unaffected.

Regarding future government partners, the party expressed a strong preference for a 'red-green' coalition with the Social Democratic Party (SPD), although by spring 2013, with the SPD polling poorly, this outcome already appeared unlikely. Consequently, the only realistic alternative was a 'black-green' coalition with the Christian Democratic Union (CDU) and its Bavarian sister party, the Christian Social Union (CSU). However, two coalitions with the CDU at state level had ended prematurely in the late $2000 \mathrm{~s}$. With most green voters placing themselves on the left, a strategy of keeping the possibility of a 'black-green' coalition open risked alienating 
Green voters who might not want to vote Green in order to prop up a new Merkel government.

\section{The Election Campaign}

Without a realistic prospect of entering government, the Greens found it difficult to mobilise their supporters. Nevertheless, the party's support remained buoyant: in early August, polls still indicated a Green vote share of 12 to $14 \%$.

This situation changed dramatically in the last few weeks of the campaign. On 5 August 2013, the popular daily paper, BILD, ran an article claiming that the Greens wanted to ban the consumption of meat. The green programme contained a passage suggesting the introduction of one meat-free day a week in canteens and staff restaurants. This 'Veggie Day' was attacked vigorously by the government parties. The Greens were accused of being a Verbotspartei, a party of prohibitions. The 'Veggie Day' as a symbol of Green interference in people's daily lives had enormous resonance and immediately became a core feature of the media narrative of the Green campaign.

The tax debate also became more prominent as the media discussed details of the Greens' reform proposals. In 2009, the tax proposals had been framed as part of a 'green new deal', with investment in green jobs seen as the best way out of the economic crisis. This link to environmental and energy problems was largely absent from the party's economic discourse in 2013.

The Green election campaign was also affected by an issue that nobody had anticipated: the influence of paedophile groups in the early history of the Green Party. The story initially focused on the Greens' leader in the European Parliament, Daniel Cohn-Bendit who in a 1975 book had made statements that were interpreted as allusions to sexual acts involving him and young children, which he later claimed were purely fictional. He had been attacked on this issue several times before but had survived politically largely unscathed. In March 2013, the issue re-emerged when Cohn-Bendit was nominated for a prestigious German prize in recognition of his social and political engagement. Against the background of recent child sex scandals in Germany, involving a leading boarding school and the Catholic Church, journalists pursued the story vigorously. Media coverage quickly extended to the positions taken by the Greens on these issues in the early 1980s, with claims that paedophile groups had played an important role in the party. With more and more stories emerging, the Greens decided in May 2013 to ask an independent academic, University of Göttingen Professor Franz Walter, to conduct a thorough investigation into the activities of paedophile groups in the Greens.

Walter's preliminary findings (Frankfurter Allgemeine Zeitung, 12 August 2013) were that the influence of paedophile groups in the 1980s had been far more widespread than previously acknowledged. The 1980 fundamental programme of the Greens (the main expression of Green values and demands until the 1993 merger between the Greens and Alliance '90) contained a passage demanding legalisation of what paedophiles claimed to be 'consensual' sex between children and adults, couched in legalistic language as a demand for the amendment of the relevant paragraph of the German penal code. Only in 1989 did the Green Party 
comprehensively distance itself from paedophile groups whose demands had subsequently been unrepresented in Green programmes.

Walter's report caused a wave of media coverage highly critical of the Greens. A few days before election day Walter published a further newspaper article that linked Trittin directly to the paedophilia issue: his name appeared, together with those of several others, as 'responsible in terms of the German press law' (a legal requirement for all German publications) on a 1981 Green local election programme in Göttingen (where Trittin was studying at the time), which contained a demand for the legalisation of 'consensual' sex between children and adults (Die Tageszeitung, 16 September 2013).

By then, the Greens had been dropping roughly one percentage point a week in the final month of the campaign to enter the election on $9 \%$.

\section{The Result}

On election night, the Greens appeared stunned by their poor result (see Table 1). Yet set in the context of their historical development, perhaps that was an overreaction: with $8.4 \%$ of 'second' votes the Greens achieved their third best result. By comparison, the FDP achieved its worst ever result, and the SPD its second worst post-war result. The Pirate Party, which had made substantial gains in regional elections during 2011 and 2012, fell well short of the 5\% threshold. Of the three small parties represented in the Bundestag that had made substantial gains in 2009, the Greens lost fewest votes and seats.

\section{--- Table 1 about here ---}

Clearly, the 2013 result was a set-back, the Greens receiving almost one million fewer votes than in 2009. Despite that, their position in parliament could arguably be seen as stronger than in 2009. With the FDP failing to return to parliament, Chancellor Merkel needed a new coalition partner. For the first time, a 'black-green' coalition of CDU/CSU and Greens had a majority and constituted one possible way for the Greens to enter government. The CDU and CSU invited the Greens to preliminary talks about a possible 'black-green' coalition. After two meetings, the Greens decided there was no basis for formal coalition negotiations, but both sides commented favourably on the talks, holding out the promise of 'black-green' coalitions in future.

As the SPD had categorically excluded the possibility of entering a coalition with the Left party, the second possibility - a 'red-red-green' coalition with the SPD and the Left Party - was never a realistic option.

\section{Analysis}

What went wrong for the Greens? The party leadership responded to the disappointing result very quickly. Claudia Roth, Renate Künast and Trittin resigned their respective positions as co-chair of the party and co-chairs of the parliamentary party, introducing a generational change in the leadership. But few blamed the result mainly on the leadership. Three issues dominated the immediate post-election discussions at the Länderrat (party state council) and full party congress: the paedophilia issue, the 
Veggie Day and the tax-raising programme. Which was most responsible for the green failure at the ballot box?

The timing of the decline in the polls suggests that the paedophilia issue hit the Greens particularly hard. After a brief hesitation, the party had decided to pursue a policy of complete openness, which some thought came too late. However, in the context of an election campaign, the release of historical research results about events of the 1980s created a nightmare scenario for the party. In the public mind, this was not just an academic discourse about some detail of Green Party history but associated Greens with the idea of legalising sexual practises involving children that are universally condemned as heinous and despicable.

One benefit of the retirement of 'veteran' Green leaders might be that the party could now be in a better position to face the accusations about the influence of paedophile groups in the 1980s and achieve a degree of closure. As one of the younger speakers at the Länderrat remarked, he was happy to have been granted the 'mercy of late birth' in terms of being too young to have been active in the Greens in the 1980s. Further research may produce more unpleasant news but if the Greens can successfully claim to have kept these groups and their demands out of the party for more than 20 years, with none of the new leadership team having been involved in a senior capacity in the party before 1993, the party should be more successful in avoiding association with these issues.

More crucial for the future policy direction of the party were debates about the Veggie Day and the tax programme. In the minds of Green campaigners, the Veggie Day loomed very large and was seen as a turning point in the election campaign. Greens found it difficult to extricate themselves from the charge of being a Verbotspartei, a state-centred, illiberal party of Besserwisser (know-it-alls) trying to force their views on an unwilling population. Across the party, this was seen as a major challenge that needed to be addressed. Party co-chair, Cem Özdemir, demanded the Greens should again become a 'party of freedom'.

Even more important in the post-election discussion was tax policy. Were voters deterred from voting Green because the party's tax policies would hit their economic position particularly hard? According to a study of the impact of the parties' tax proposals on their own voters, the Greens' programme punished their own supporters very harshly while most other parties' tax policies were designed to benefit their own voters (Peichl et al. 2013). A move of affluent Greens away from the party for reasons of personal economic gain would be consistent with a trend in German public attitudes in recent years, which Wilhelm Heitmeyer (2010) has termed 'desolidarisation'. Heitmeyer's annual surveys show that neo-liberal thinking on social justice and the welfare state had an increasing impact on Germany during the 2000s, affluent Germans increasingly blaming the poor for their own predicament and regarding them as less worthy of state support. If this trend also affects affluent (potential) Green voters, it is bad news for the electoral appeal of a Green Party promoting social and economic policies directed at redistribution and greater social justice. Those sections of the population who would benefit most from Green tax policies are most likely to vote for the Left party or not at all, since non-voting is closely linked with economic deprivation, and the negative effect of low social class on turnout at elections appears to become stronger over time (Petersen et al. 2013). 
A rival explanation for the unpopularity of the Green tax-raising proposals focuses on the core competence of the party. Asked which party has the highest competence in dealing with specific policies, the Greens in 2013, with 35\%, were seen as the most competent party on energy policy. But the most competent party on social justice was the SPD, also with 35\%, while the Greens did not feature at all (Forschungsgruppe Wahlen 2013, p. 33). A voter choosing between voting Green or SPD who is mainly motivated by social justice issues could thus be expected to have voted for the SPD, particularly as a 'red-green' government was unlikely, and as supporting the SPD might strengthen its position in a 'grand coalition'. Analysis of voter movements by Infratest dimap showed that the Greens suffered a net loss of 550,000 voters to the SPD and 450,000 to the CDU/CSU (Frankfurter Allgemeine Zeitung, 24 September 2013).

Beyond these issues, the major focus of the internal party debate concerned the lack of any realistic prospect of Greens entering government. After three failed campaigns to secure a 'red-green' government, there is consensus in the party that such an exclusive strategy should be discontinued. The October party congress passed a motion calling for a wider set of options for future coalition formation, with both 'black-green' and 'red-red-green' coalitions mentioned. However, it is difficult to imagine that the party could enter future federal elections without an expressed preference for a coalition partner. The coalition question also risks reviving factional divisions within the party, the Realos favouring a move to 'black-green' while the Left prefers 'red-red-green'.

Nevertheless, the party is committed to avoiding open conflict between the two factions, as demonstrated by the smooth change of leadership after the elections. Yet factional allegiance continues to play a major role for political careers in the party: Simone Peter, the new party co-chair, and Anton Hofreiter, the new parliamentary coleader, both associated with the Left faction, 'emerged' from relative obscurity to become undisputed candidates for these positions.

\section{Conclusion}

Once the disappointment of the 2013 result has receded, a closer look at the current position of the party will reveal substantial strengths. The party survived an extremely difficult election campaign and knows it can rely on around 3.7 million voters come what may. Given the demographic development, which will see the generations most influenced by green thinking increase in size in coming years (Rüdig 2012), the fundamentals are in place for further growth. Assuming that the Greens spend the next four years in opposition to a 'grand coalition', the party will play an important role as one of two opposition parties of virtually identical size to counter a government with an overwhelming majority. Moreover, because the grand coalition does not command a majority of votes in the Bundesrat, the upper chamber of parliament, the Greens (as coalition partner in six regional governments) are in a fairly strong position to influence important federal legislation.

Small parties have always benefitted electorally from 'grand coalitions'. An improved result in 2017 may thus be expected, although the salience of the Green core environmental and energy issues will also play a role. Key choices in the next four year will likely to be made in the Länder: the chances for a 'black-green' coalition at 
federal level would be greatly enhanced if such governments could successfully be formed at regional level. A first regional 'red-red-green' coalition in West Germany would send a strong signal that the Left party could finally be accepted as a potential coalition partner at federal level. Thus, despite the disappointment of 2013, there are strong indications that the future might still be bright for the Greens in Germany but in which political direction this will take the party is far more difficult to predict. 
Table 1: Result of the German Federal Elections of 22 September 2013

\begin{tabular}{|l|c|c|c|c|}
\hline Party & $\begin{array}{c}\text { Share of the } \\
\text { (Second) } \\
\text { Vote (\%) }\end{array}$ & $\begin{array}{c}\text { Difference } \\
\text { from 2009 }\end{array}$ & Seats & $\begin{array}{c}\text { Difference } \\
\text { from 2009 }\end{array}$ \\
\hline CDU/CSU & 41.5 & +7.7 & 311 & +72 \\
\hline SPD & 25.7 & +2.7 & 193 & +47 \\
\hline The Left & 8.6 & -3.3 & 64 & -12 \\
\hline Greens & 8.4 & -2.3 & 63 & -5 \\
\hline & & & & -93 \\
\hline FDP & 4.8 & -9.8 & 0 & - \\
\hline AFD & 4.7 & +4.7 & 0 & - \\
\hline Pirates & 2.2 & +0.2 & 0 & \\
\hline
\end{tabular}

Source: Federal Returning Officer, http://www.bundeswahlleiter.de

German Parties:

CDU Christlich-Demokratische Union (Christian-Democratic Union)

CSU Christlich-Soziale Union (Christian-Social Union)

SPD Sozialdemokratische Partei Deutschlands (Social Democratic Party of Germany)

The Left Die Linke (The Left)

Greens Bündnis '90/Die Grünen (Alliance '90/The Greens)

FDP Freie Demokratische Partei (Free Democratic Party)

AFD Alternative für Deutschland (Alternative for Germany)

Pirates Piratenpartei Deutschlands (Pirate Party of Germany) 


\section{References}

Forschungsgruppe Wahlen (2013) Bundestagswahl: Eine Analyse der Wahl vom 22. September 2013 (Berichte der Forschungsgruppe Wahlen e.V., No. 154)(Mannheim: Forschungsgruppe Wahlen).

Heitmeyer, W. (2010), 'Disparate Entwicklungen in Krisenzeiten, Entsolidarisierung und Gruppenbezogene Menschenfeindlichkeit', in: Heitmeyer, W. (ed.), Deutsche Zustände: Folge 9 (Frankfurt am Main: Suhrkamp), pp. 13-33.

Petersen, T.; Hierlemann, D.; Vehrkamp, R. B. and Wratil, C. (2013) Gespaltene Demokratie: Politische Partizipation und Demokratiezufriendenheit vor der Bundestagswahl 2013 (Gütersloh: Bertelsmann Stiftung).

Peichl, A.; Pestel, N.; Siegloch, S. and Sommer, E. (2013) 'Bundestagswahlkampf 2013: Klientelpolitik durch Steuerreform?’, IZA Standpunkte, Nr. 59 (Bonn: Institut zur Zukunft der Arbeit), http://ftp.iza.org/sp59.pdf

Rüdig, W. (2012), 'The perennial success of the German Greens', Environmental Politics, Vol. 21, No. 1, pp. 108-130. 


\section{NOTES}

${ }^{1}$ I am grateful to the German Academic Exchange Service (DAAD) and the International Association for the Study of German Politics (IASGP) as well as Dan Hough and Martine Huberty of the University of Sussex for organising a visit that allowed me to attend briefings by party campaigners as well as observe election rallies in September 2013. I also thank E. Gene Frankland and other observers for helpful discussion on green politics in Germany. This account is based on the observation of the election campaign in Berlin and the study of the German media, including the main newspapers and TV stations

${ }^{2}$ For all polling data and electoral results, see http://www.wahlrecht.de 